\title{
11
}

\section{Ichthyoarchaeological Investigation of Neolithic to Recent Fishing Practices in the Batanes Islands}

\author{
Fredeliza Campos
}

The recovery of fish bone assemblages of Neolithic to recent date (1200 BC to AD 1500) in Batanes has generated significant new information on the early fishing practices of the region. As part of a wide-ranging project to understand the palaeoenvironmental history and human prehistory of the islands, the analysis of the fish remains suggests utilization of inshore and offshore marine species dating back as far as $1200 \mathrm{BC}$. In particular, the results show consumption of the common dolphinfish Coryphaena hippurus L., a pelagic bony fish hunted and much revered by the present-day inhabitants of the islands. The presence of the dolphinfish in the archaeological record demonstrates the antiquity of an open ocean fishing tradition, implying an ability to construct sophisticated fishing vessels. The study also examines butchery techniques and fish processing in the prehistory of the region.

The analysis of fish remains is essential to understanding past maritime subsistence strategies, particularly in island communities such as the Philippines. The country has a large aquatic resource base that forms part of the most diverse marine community in the world (Carpenter and Springer 2005; Ekman 1953). The seas off the Philippine Islands with their long coastlines support an abundance of fish, with a recent count of over 3000 marine species (Froese and Pauly 2012), providing an easily accessible food resource. Fish constitute a big portion of the Filipino diet and by far the largest source of protein in that diet (Florentino 1996; Florentino et al. 1985).

However, the overall role of fish in Philippine prehistory has not been clearly established. Substantial analysis and interpretation of fish remains recovered from archaeological sites has been scarce, both within the country and in Southeast Asia generally. Mudar (1997) included fish remains in her assessment of past animal consumption in four archaeological sites: Plaza Independencia $\left(14^{\text {th }}\right.$ century AD) and Santo Niño (AD 1350 - 1900) in Cebu City, Tanjay (AD 1000 - 1600) on Negros, and Sohoton I Cave (after 8500 BC) on Samar. Sohoton 1 is of particular interest because it indicates catching of inshore reef fishes before the Neolithic, and transport from the coast to the cave. Elsewhere in Southeast Asia, Neolithic (1400 - 500 BC) 
fishing strategies of the inhabitants of Bukit Tengkorak on the east coast of northern Borneo have been explored (Ono 2004), as well as in southern Taiwan (Li 1989, 2000). Interestingly, these studies underscore reliance on reef fish and only minimal exploitation of pelagic fish.

For freshwater species, several studies have focused on fishing strategies within the Mekong River system. For instance, riverine fish remains have been identified from several archaeological sites in Cambodia (Voeun 2003). Thosarat (2010) has examined fishing strategies at the Neolithic site of Ban Non Wat (starting c.1700 BC) in northeast Thailand. Piper et al. (2012) discuss fishing in the early agricultural settlement site of An Son (starting c.2000 BC) in southern Vietnam. The presence of freshwater fish in the huge shell middens of the Cagayan Valley (1000 BC to AD 500) has been reported since 1987 (Garong and Toizumi 2000), but earlier excavations such as those conducted by Cabanilla (1972) and Thiel (1989) did not report substantial fish bone assemblages. All of these studies have strengthened the burgeoning field of ichthyoarchaeology in the region, and should now expand into the study of fish butchery, a topic virtually untouched in the archaeology of Southeast Asia.

In the Batanes Islands, the fish bones recovered by the initial Philippine-Australian excavations on Batan in 2002 were analysed by Szabó et al. (2003). Their relatively small numbers, due to an initial concentration on rock shelter occupations, implied that fishing was only an occasional subsistence pursuit. This contradicted both early and modern-day accounts that described fishing, along with livestock, as principal livelihoods among the local inhabitants (see chapter 2). However, the succeeding open site excavations on Itbayat and Sabtang Islands produced denser fish bone fragments, which underpin the research reported here. These remains form one of the largest fish bone assemblages so far encountered in Philippine archaeology.

Three sites in Batanes were covered for this study: Anaro on Itbayat, with Savidug Dune Site (Nadapis) and Pamayan on Sabtang. These sites contain important chronological sequences from an early phase of habitation (though not the earliest) around $1200 \mathrm{BC}$ to the period just before European contact. The study reveals that some of the contemporary fishing traditions and methods of preparation observed among Batanes inhabitants have a deep antiquity, particularly exploitation of the common dolphinfish, Coryphaena hippurus Linneaus, 1758 (Perciformes: Coryphaenidae).

\section{The fish bone assemblage}

In total, the assemblage consists of 2396 fish bone fragments from the above-mentioned excavation sites. Due to logistical problems with sieving, the bones from Anaro were hand-collected, and this has inevitably biased the assemblage towards large, easily identifiable fragments. The larger assemblages from Savidug Dune Site and Pamayan were dry sieved and all fragments were collected.

The fish bones were primarily identified through direct morphological comparison using the modern comparative collection of tropical fish established by the author for the Archaeological Studies Program at the University of the Philippines (UP-ASP 2010). Initial segregation and preliminary identification procedures followed Leach $(1986,1997)$. Other prominent neurocranial, appendicular and axial elements, particularly vertebrae, were also analysed. Selected bone fragments and all anthropogenic modifications, such as cut and scrape marks, were identified according to osteoarchaeological conventions (Potts and Shipman 1981), acknowledging that materials other than stone could potentially have been used in the butchery process (see Campos 2009 for full analytical data).

Due to the high diversity of fishes in tropical seas, it is difficult in most cases to identify fish bones to anything higher than family level. An exception is the common dolphinfish, for which 
the distinctive porosity and morphology of its skeletal elements make identification possible to species level. On the other hand, family-level identifications for the subclass Elasmobranchii could not be made due to the lack of a sufficient comparative collection. The overall size of the assemblage did not permit meaningful comparisons in potential variability in fishing strategy between sites and time periods. But the presence and absence of certain fish taxa provide evidence for the fishing strategies employed on both Itbayat and Sabtang islands.

The species identification of Coryphaenidae permitted an approximation of body lengths, based on modern comparative specimens. The method employed is modified from Casteel (1976) using equation $L / Q_{1}=L / Q_{2}$; where $L_{1}$ is the unknown snout-to-tail length or total length (TL) of the excavated fish; $L_{2}$ is the known TL of the comparative fish specimen. $Q$ represents measurements of the vertebra: $Q_{1}$ is either the antero-posterior length, dorso-ventral depth, or medio-lateral width (cranial and caudal end) measured from the excavated vertebral fragment; and $Q_{2}$ is the corresponding measurement from the comparative vertebra. The weights of the archaeological specimens were estimated based on modern weights of Coryphaenidae recorded by Uchiyama and Boggs (2006). However, distribution of body fat varies tremendously between individuals, so these estimated weights should only be considered as an approximate supplement to the calculated TL.

\section{Taxonomic representation}

The smallest fish bone assemblage was recovered from Anaro and consists of 210 fragments, of which 65 could be identified to taxon. Nonetheless, the assemblage is relatively diverse considering its size. It contains Elasmobranchii (sharks and/or rays), Serranidae (groupers), Lutjanidae (snappers), Haemulidae (sweetlips), Sparidae (sea breams), Lethrinidae (emperors), Carangidae (jacks and trevallies), Coyphaenidae (dolphinfish), Labridae (wrasses), Scaridae (parrotfish), Siganidae (rabbitfishes), Sphyraenidae (barracudas), Scombridae (tunas and mackerels), Balistidae (triggerfish), Tetraodontidae (pufferfish), and Diodontidae (porcupine fish). The results suggest that a variety of reef fishes were caught along with the pelagic dolphinfish during the occupation of the Anaro site.

Of the 885 fragments analysed from Savidug Dune Site, 544 could be confidently assigned to the layer 2 upper cultural horizon, and a further 341 fragments to the lower cultural horizon in layers 4 and 5, all from Trench Q/R 7-9 below $1.2 \mathrm{~m}$ depth. The raw NISP calculations show a predominance of Diodontidae (43.4\%) (Table 11.1), but this merely reflects the quantity and toughness of the dermal spines. These sharp, specialized fish scales cover certain species for protection against predators and considerably outnumber recognized skeletal elements in other teleosts. Their robustness, high resistance to decay and abundance in a single individual means that they substantially elevate the NISP for the taxon beyond their overall importance within the assemblage. Of note is the high number of Coryphaenidae fragments $(n=91)$ identified in layer 2 , which even exceeded Diodontidae $(n=73)$.

All three layers in Savidug Dune Site contain a variety of inshore and offshore fishes, similar in Anaro, but with the addition of Acanthuridae (surgeonfish) and the absence of Tetraodontidae (Table 11.1). It appears that a variety of techniques were used in inshore reef fishing. There was, however, a notable difference in the numbers of Coryphaenidae remains recovered between layers. In layer 2, 36\% of the identified fish remains are Coryphaenidae, represented primarily by vertebrae $(n=74)$. In archaeology, fish identification using vertebrae can be unreliable, but in the case of the common dolphinfish this particular element is characteristic of the species. Other elements, namely premaxilla, maxilla, articular, preopercle, subopercle, and dentary also represent Coryphaenidae, and support its definite occurrence, if not prominence, in this layer. Several pharyngeal teeth and cranial elements from other fish taxa are also recorded, suggesting that 
most anatomical elements were introduced into the site. The abrupt decrease of Coryphaenidae in layer $4(n=4)$ would seem to suggest a marked increase in the importance of dolphinfish from the prehistoric to protohistoric periods, but this is contradicted by their rarity at Pamayan, discussed below. The basal deposits of Savidug Dune Site contained only 26 identifiable fish bone fragments, which were of Serranidae, Lethrinidae, Carangidae, Coryphaenidae, Scaridae, Acanthuridae, Balistidae and Diondontidae.

The Pamayan shell midden at the back of Savidug village is roughly contemporary with layer 2 at Savidug, with Song dynasty and later Chinese import ceramics and a basal date of AD 14201630 (see chapter 5). It yielded a total of 1328 fish bones, of which 355 (26.73\%) were identified to taxon (Table 11.1). Fifteen fish taxa were identified in the assemblage, with Diodontidae and Acanthuridae the most abundant based on their numerous spines and pterygiophores. Other bones were identified as Serranidae, Carangidae, Coryphaenidae, Lutjanidae, Lethrinidae, Labridae, Scaridae, Siganidae, Scombridae, Balistidae, and Tetraodontidae. Additionally, two taxa not recorded at Anaro or Savidug but present in the Pamayan assemblage included Belonidae (needlefish) and Nemipteridae (threadfin bream). However, in contrast to layer 2 at Savidug, the Pamayan assemblage contained only three $(0.8 \%)$ Coryphaenidae vertebrae. Planar (anteroposterior) lengths of complete vertebrae fragments were taken which reflect relative sizes of individuals, and these measurements show that the Pamayan fish bones were markedly smaller $(2-20 \mathrm{~mm})$ than those from Savidug $(4-40 \mathrm{~mm})$.

The occurrence of Coryphaena hippurus in all three sites presents an opportunity to estimate the sizes of this fish caught in prehistory. With approximately $\pm 100 \mathrm{~mm}$ variation from the estimated lengths, the archaeological specimens were caught as adults but most likely had not yet reached maximum sizes. The majority were estimated to have been between $1 \mathrm{~m}$ and $1.4 \mathrm{~m}$ in length (snout-to-tail length or TL; Tables 11.2 and 11.3). Although more than one vertebra could potentially have come from the same individual in layer 2 , the distribution of calculated TLs in the assemblage suggests that several individuals of different length are represented. Modern fisheries data for this species in the northern Pacific, regularly caught in Hawaiian waters, suggest body weights of as much as $29 \mathrm{~kg}$ for $1.5 \mathrm{~m}$ long females (Uchiyama and Boggs 2006). From Savidug Dune Site, the largest estimated individual was around $2 \mathrm{~m}$ in length, similar to the maximum size reported for modern common dolphfinfish (Allen 2000; Broad 2003). A dolphinfish of this size can weigh up to $40 \mathrm{~kg}$ (Burton and Burton 2002; Massutí 1997).

\section{Butchery and fish processing}

Though cut marks are generally rare on archaeological fish bones (Colley 1990: 216-217; Lyman 1994: 439), at least 34 Batanes fragments bear distinct cut, chop, and scrape marks (Table 11.4). The modified bones include vertebrae, vertebral spines, dorsal and fin spines, dermal spines, pharyngeal plates and, notably, a Coryphaenidae right dentary. These cut marks further verify the human consumption of reef fishes from families such as the Carangidae, Balistidae and Diodontidae, as well as the pelagic Coryphaenidae. The locations of the cut marks on the lateral surfaces of vertebrae suggest filleting and the division of the carcass into pieces, and scraping off meat closely attached to the axial skeleton. The marks concentrated along the opercular areas and posterior cephalic vertebra strongly suggest common fish preparation processes such as the removal of gill rakers and other internal organs. The excision of spinous structures, such as the sharp first dorsal spine of the Balistidae (Fig. 11.1) and the dermal spines of Diodontidae (Fig. 11.2) are techniques used by contemporary fishermen of the Batanes Islands, wherein the latter were often deliberately burned or buried on site (Paz et al. 1998). 


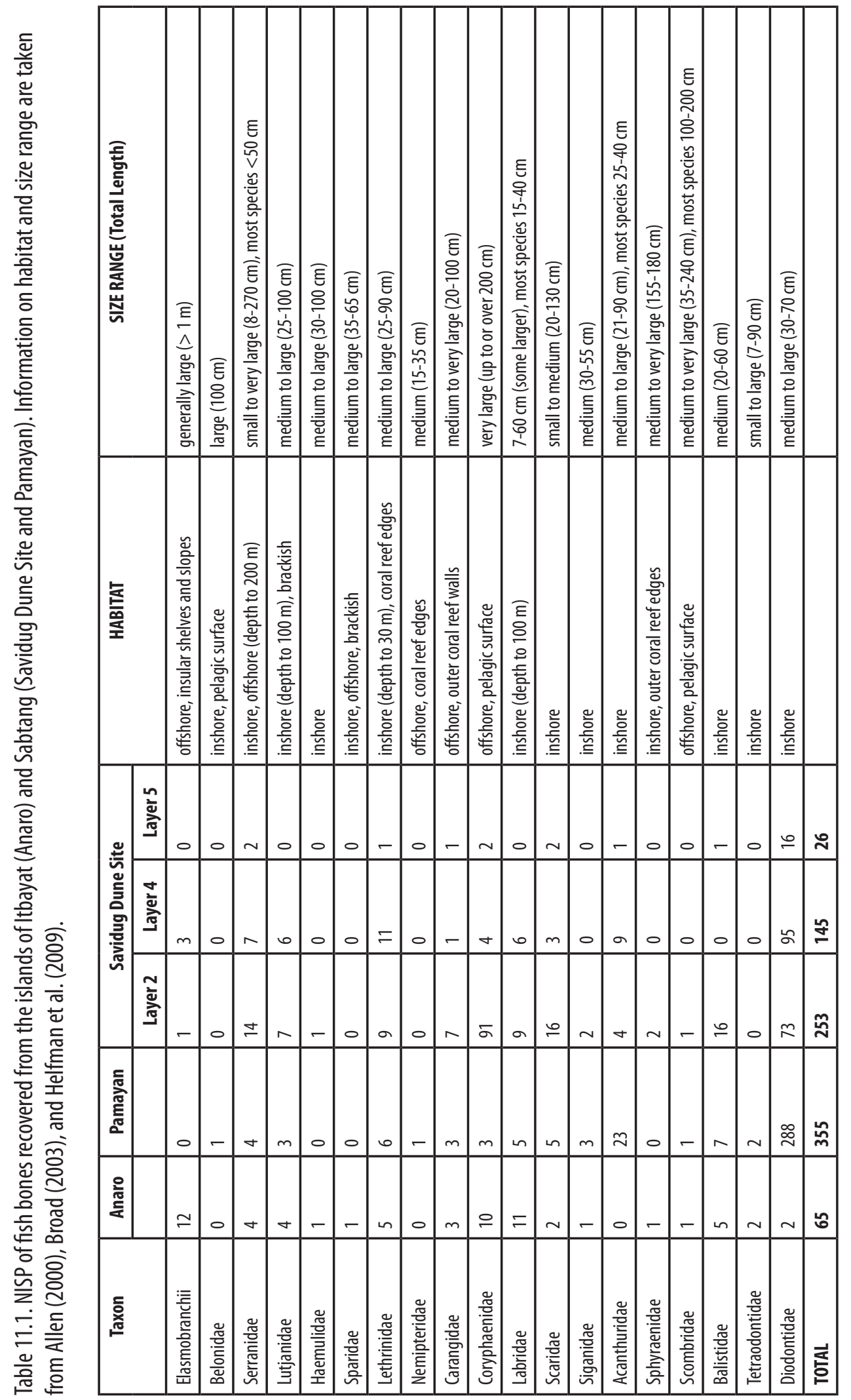


Table 11.2. Estimated TL (cm) of Coryphaenidae calculated from the abdominal vertebrae found in Layer 2 of the Savidug Dune Site. The resultant values are considered to be no more than general estimates of head to fork length. Ant1 $=$ Anterior medio-lateral width; Ant2 $=$ Anterior dorso-ventral width; Post $1=$ Posterior medio-lateral width; Post2 $=$ Posterior dorso-ventral width.

\begin{tabular}{|l|l|l|l|l|l|l|l|l|}
\hline Specimen No. & Square No. & Depth $(\mathbf{c m})$ & Length & Ant1 & Ant2 & Post1 & Post2 & Average (Approx.) length (cm) \\
\hline SB189 & C-11 & $50-60$ & - & 199.9 & 206.7 & - & - & 203.3 \\
\hline SB130 & B-10 & $70-100$ & 148.4 & - & - & - & 154.5 & 148.5 \\
\hline SB131 & B-11 & $80-90$ & - & 141.2 & 145 & - & - & 143.1 \\
\hline SB195 & C-10 & $60-70$ & 134.5 & 124 & 129.4 & 121.9 & 134.3 & 128.8 \\
\hline SB100 & B-10 & $70-100$ & 131.5 & 135.8 & 129.3 & 117.1 & 127.5 & 128.2 \\
\hline SB66 & B-10 & $50-60$ & 136.2 & 122.6 & 126.2 & 121.1 & 128.6 & 126.9 \\
\hline SB3 & A-9 & $60-70$ & 129.9 & 119.9 & 127.3 & 123.1 & 130.1 & 126.1 \\
\hline SB148 & B-11 & $90-100$ & - & 122.3 & 121.8 & - & - & 122.1 \\
\hline SB190 & C-10 & $40-60$ & - & 122.2 & 127.1 & 118.6 & 120.2 & 122 \\
\hline SB50 & B-10 & $20-40$ & 102 & 121 & 124.9 & 131 & 120 & 119.8 \\
\hline SB1 & A-9 & $50-60$ & 115.7 & 110.7 & 129.9 & - & 105.6 & 115.5 \\
\hline SB51 & B-10 & $50-60$ & - & 984.2 & - & - & - & 98.4 \\
\hline
\end{tabular}

Table 11.3. Estimated TLs (cm) of Coryphaenidae based on the caudal vertebrae found in Savidug Dune Site, Layer 2. The resultant values are considered to be no more than general estimates of head to fork length (TL).

\begin{tabular}{|c|c|c|c|c|c|c|c|c|}
\hline Specimen & Square & Depth (cm) & \begin{tabular}{|l} 
Vertebra \\
length
\end{tabular} & $\begin{array}{l}\text { Anterior medio- } \\
\text { lateral width }\end{array}$ & $\begin{array}{l}\text { Anterior dorso- } \\
\text { ventral width }\end{array}$ & $\begin{array}{l}\text { Posterior medio- } \\
\text { lateral width }\end{array}$ & $\begin{array}{l}\text { Posterior dorso- } \\
\text { ventral width }\end{array}$ & $\begin{array}{l}\text { Average } \\
\text { (approx.) length (cm) }\end{array}$ \\
\hline SB18 & $A-9$ & $90-100$ & 148.5 & - & - & - & - & 148.5 \\
\hline SB102 & B-10 & $70-100$ & 158.1 & - & 138.5 & - & 140.8 & 145.8 \\
\hline SB171 & $C-10$ & $40-50$ & - & 136.2 & 137.7 & - & - & 136.9 \\
\hline SB319 & $C-10$ & $70-80$ & 134.4 & 127 & - & - & 144.2 & 135.2 \\
\hline SB146 & B-11 & $90-100$ & 138.1 & 132.9 & 127.5 & 138.1 & 131.2 & 133.5 \\
\hline SB68 & B-10 & $50-60$ & 143.3 & 121.1 & 126.8 & - & - & 130.4 \\
\hline SB30 & B-9 & $50-60$ & 126.2 & 126.6 & 139.4 & 108.9 & 124 & 125 \\
\hline SB69 & B-10 & $50-60$ & - & - & - & 121.6 & 127.9 & 124.7 \\
\hline SB35 & B-9 & $70-80$ & 141.5 & - & 118.2 & 114.6 & 122.3 & 124.2 \\
\hline SB155 & B-11 & $60-70$ & - & 123.7 & 123.9 & - & - & 123.8 \\
\hline SB65 & B-10 & $50-60$ & - & 120.4 & 127 & - & - & 123.7 \\
\hline SB167 & C-9 & $40-50$ & - & 119.9 & 124.9 & - & - & 122.4 \\
\hline SB147 & B-11 & $90-100$ & 128.4 & 118.5 & 127.2 & 110.8 & - & 121.2 \\
\hline SB67 & B-10 & $50-60$ & 124.4 & 112.7 & 119.9 & 110.8 & 120.2 & 117.6 \\
\hline SB197 & $C-10$ & $60-70$ & 107 & - & 124 & 121 & 117.3 & 117.3 \\
\hline SB48 & B-9 & $80-90$ & 111 & - & - & 111.7 & 118 & 113.6 \\
\hline SB31 & B-9 & $50-60$ & 112.9 & 110.9 & 115.5 & 109.8 & 105.6 & 110.9 \\
\hline SB192 & $C-10$ & $50-60$ & - & 109.2 & 111.3 & - & - & 110 \\
\hline SB149 & B-11 & $90-100$ & 118.7 & 103.1 & 109.2 & 107 & 111.2 & 109.9 \\
\hline SB101 & B-10 & $70-100$ & 116.9 & - & - & 101.7 & 109.1 & 109.2 \\
\hline SB48 & A-9 & $60-70$ & 105.8 & - & 101.9 & 96.2 & 101 & 101.2 \\
\hline SB150 & B-11 & $90-100$ & 98.6 & - & - & - & - & 98.6 \\
\hline SB64 & B-10 & $50-60$ & 69.2 & 80.9 & - & 80 & 76.9 & 76.7 \\
\hline
\end{tabular}

Source: Primary data assembled by the author. 


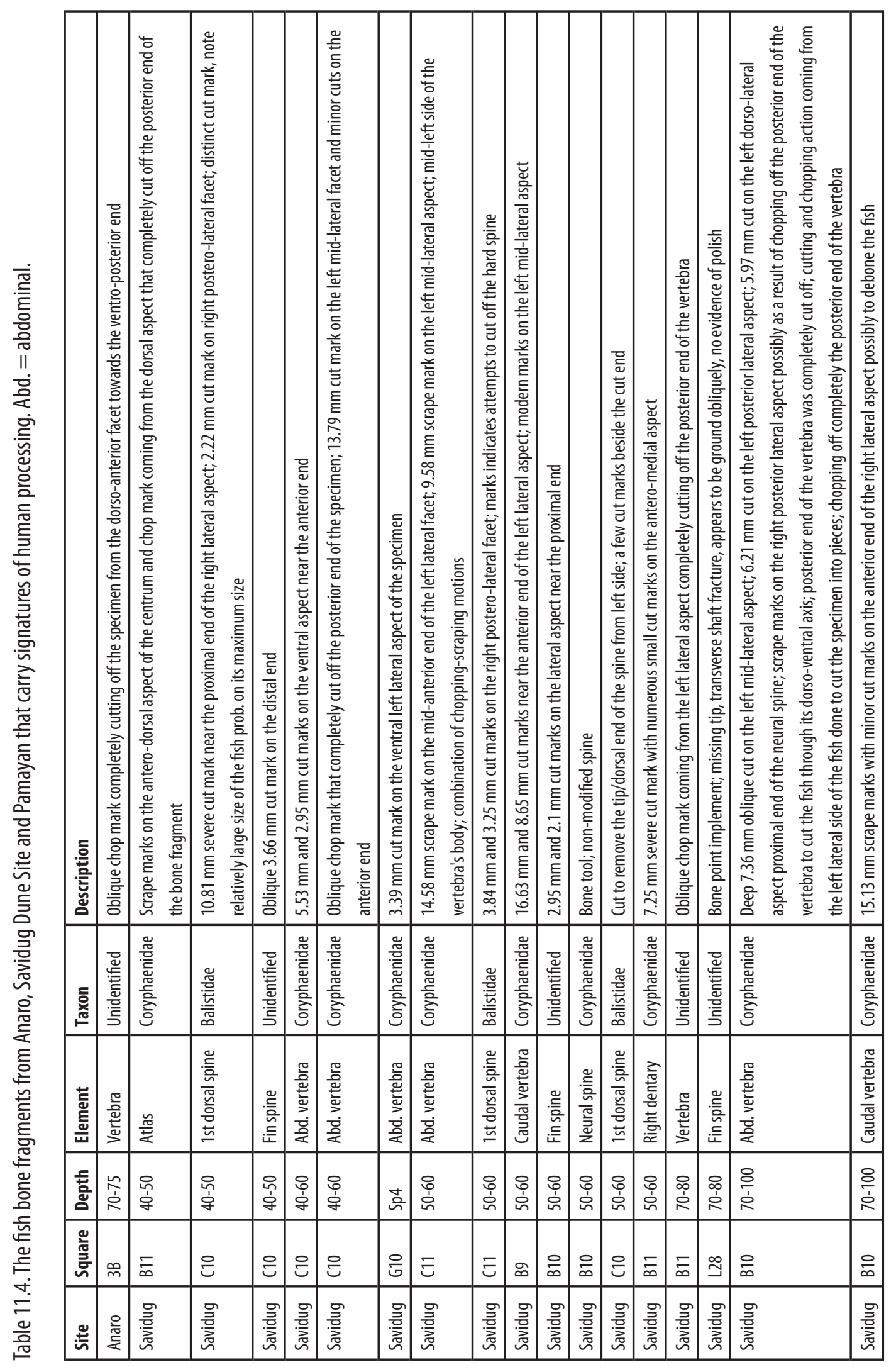




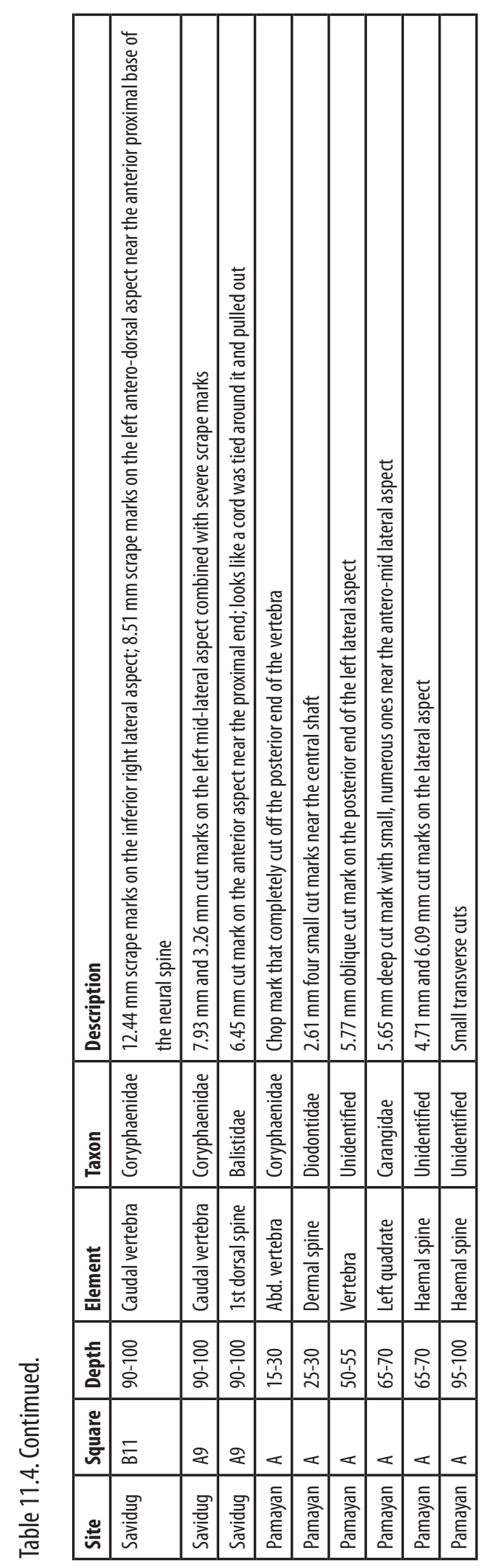




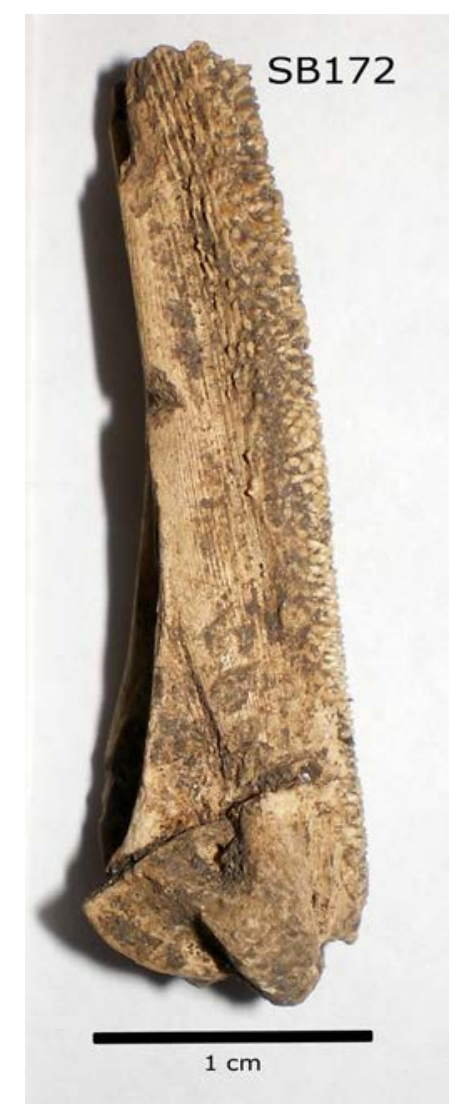

Figure 11.1. Deep oblique cut mark on the right lateral aspect near the base of a Balistidae $1^{\text {st }}$ dorsal spine from Savidug Dune Site.

Source: Fredeliza Campos.

The most striking butchery evidence recorded is on Coryphaenidae vertebrae, which suggests methods of carcass preparation. Cut and chop marks on the ends and through vertebrae can possibly be explained by misplaced attempts to divide the carcass by cutting between adjoining vertebrae. For example, a Coryphaenidae cephalic vertebra has been sliced through from the dorsal aspect, with a right hand rotation through the lateral left side to the ventral margins, and an atlas has been cut in half at an approximate $55^{\circ}$ angle, with only the caudal portion remaining. The angle suggests a cut made from the left side from the dorso-caudal aspect towards the ventrocranial aspect. Both these examples resulted in the decapitation of the fish. Interestingly, cut and scrape marks associated with filleting were generally located on the left lateral aspect of vertebrae $(n=8)$, compared with just one on the right side. Synthesizing the location and orientation of butchery signatures, it can be suggested that filleting of fish was often undertaken by a righthanded person. The cut mark shown in Fig. 11.3 and the scrape marks in Fig. 11.4 are all located on the left lateral side, and the orientation and morphology of the modifications show directionality from caudal end (tail) towards the cranial end (head). It could be surmised that the fish was laid on a surface with its head being held in the weaker left hand, the stronger right hand held the cutting implement, and the filleting motions were from the caudal towards the cranial end of the fish. Cutting in this direction permits the butcher to pass the knife between the overlapping scales, making de-scaling and de-skinning easier. 


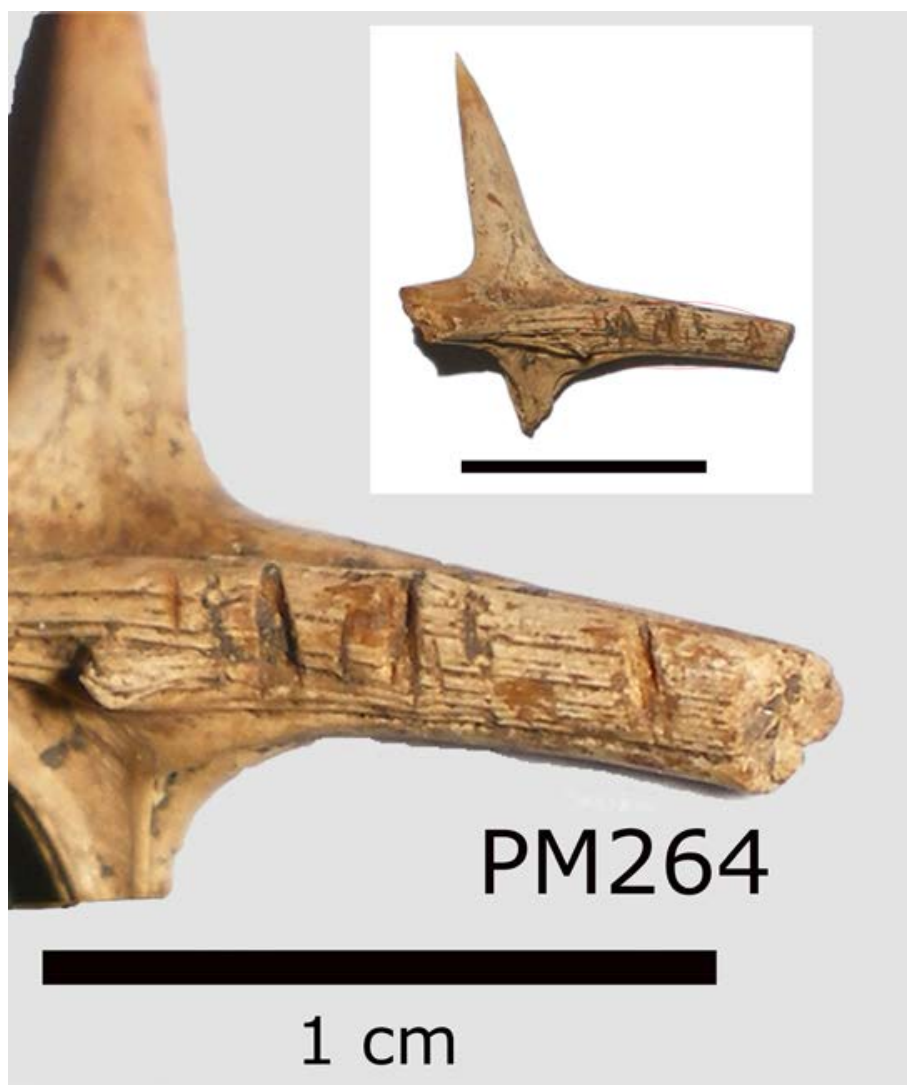

Figure 11.2. Prominent anthropogenic marks on Diodontidae dermal spines from Pamayan.

Source: Fredeliza Campos.

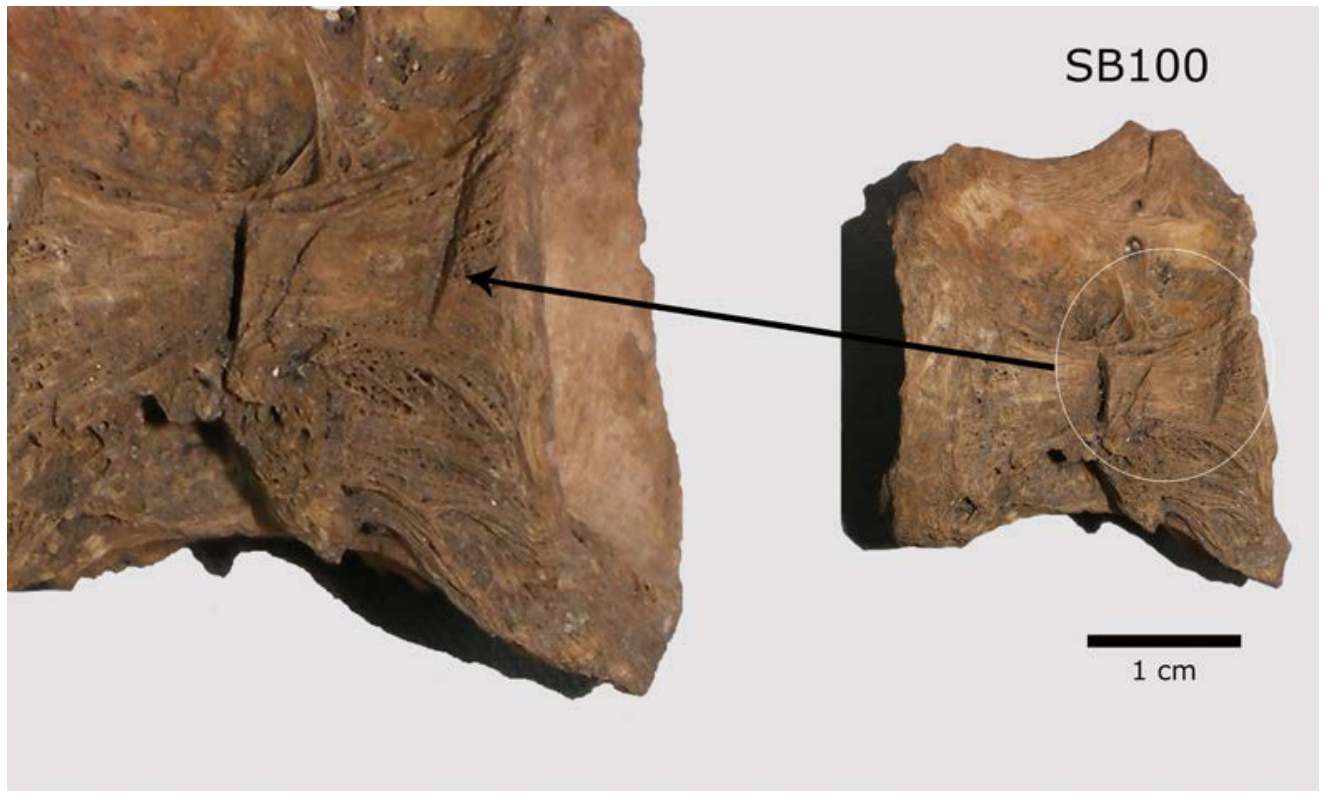

Figure 11.3. Two large dorso-ventral orientated cut marks on the left lateral aspect of a Coryphaenidae abdominal vertebra from Savidug Dune Site.

Source: Fredeliza Campos. 


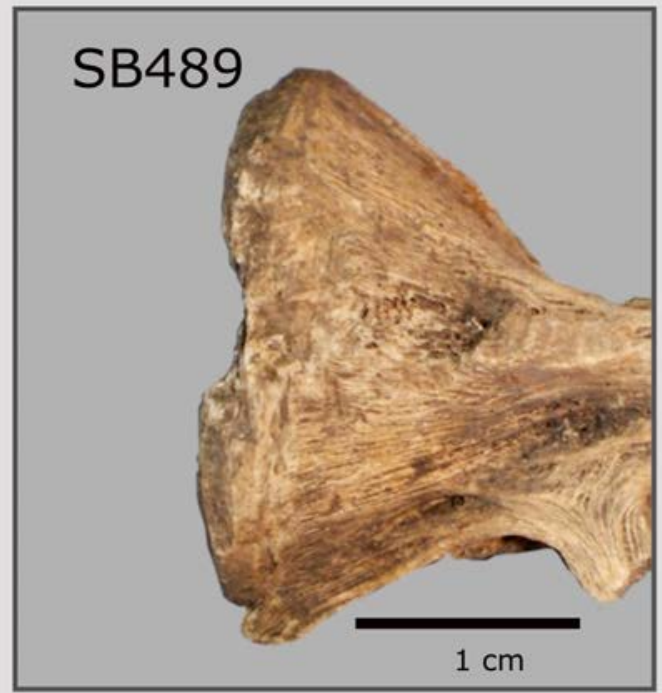

SB19

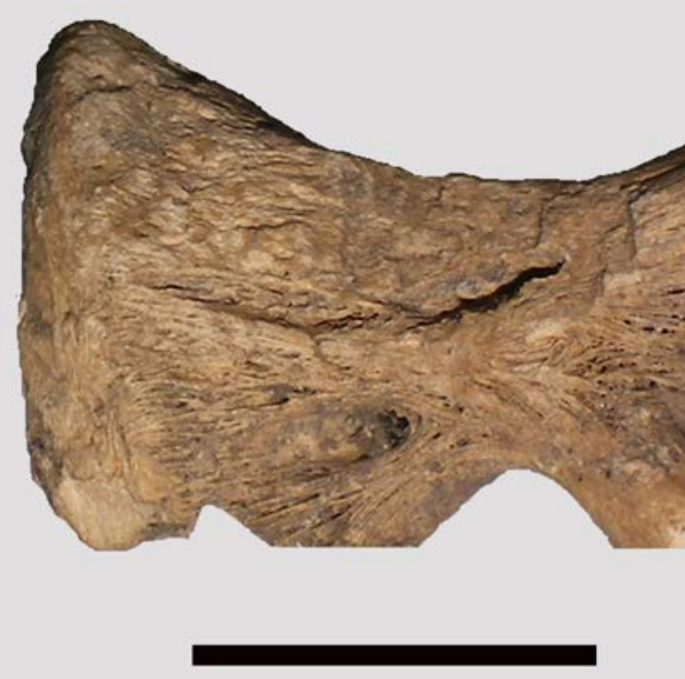

$1 \mathrm{~cm}$

Figure 11.4. Scrape marks on the dorsal surfaces of the left lateral aspect of two Coryphaenidae vertebrae from Savidug Dune Site.

Source: Fredeliza Campos.

In the markets of Manila, contemporary fishmongers employ similar methods of filleting fish. The difference is that they remove the fillets from both sides of the vertebral column, a tradition not observed in the Batanes fish bones, where cut and scrape marks were found mostly on one side of the vertebrae. This butchery pattern can be explained by the modern Ivatan tradition of removing just one large fillet from a single side of the carcass along the vertebral column, sometimes decapitating the fish, and then hanging both fillets out to dry on a large wooden rack (Fig. 11.5). The earliest examples of this type of butchery on a Coryphaenidae vertebra was from Savidug Dune Site QR 7-9 at 100-110 cm (lower cultural layer), with other examples within the younger layer 2 and Pamayan assemblages. This would suggest that the practice of dolphinfish filleting and hanging on drying racks could potentially extend back at least 2500 years, and appears to have continued until the present time. Archaeological evidence from Anaro for methods of dolphinfish processing is currently still lacking.

\section{Discussion}

The ichthyoarchaeological materials from Batanes present opportunities for a critical assessment of the role of fish in the diet of the early inhabitants of the islands. There are at least 1 subclass, 17 families and 1 species in the combined faunal assemblages. It appears a variety of common inshore reef fishes, including groupers, snappers, parrotfishes, emperors, jacks/trevallies and triggerfishes were being caught around the coasts. Table 11.1 lists the diverse habitats of these fishes and implies that varying strategies must have been employed in relation to what could be caught throughout the year. Vertebrae length measurements show that the largest fish caught were the inshore emperor fish (Lethrinidae) and the pelagic dolphinfish (Coryphaenidae).

Yang (2006) has recorded notched stone fishing sinkers in the archaeological record from Batan Island dating to as early as $1200 \mathrm{BC}$ (chapter 8), and more examples were recovered from Savidug. 
Stone sinkers can be used either for nets or tied to fishing lines as weights. Some cut pieces of shell, also from Anaro 3, look very similar to the shell hook preforms illustrated by Li (2002: 63) from Eluanbi in southern Taiwan (see chapters 8 and 12 for discussion of the Anaro examples). Perforated Turbo long units from the upper cultural layer at Savidug are also discussed in chapter 8 , and the tentative suggestion is made there that they might have been trolling lure shanks, used with thorn or bone points. Indeed, fishing gorges produced from a male pig lower canine and bone have been identified in the archaeological record from the Cagayan valley (Piper et al. 2009), and these would have been effective for capturing carnivorous fish with relatively large mouth sizes, such as the Serranidae. During the 2005 excavation at Anaro, at least three similar fishing gorges were found (Fig. 11.6). Their sizes indicate that medium to big individuals (over $50 \mathrm{~cm}$ long) and species more resistant to being caught in nets, such as parrotfish and triggerfish, were being targeted.

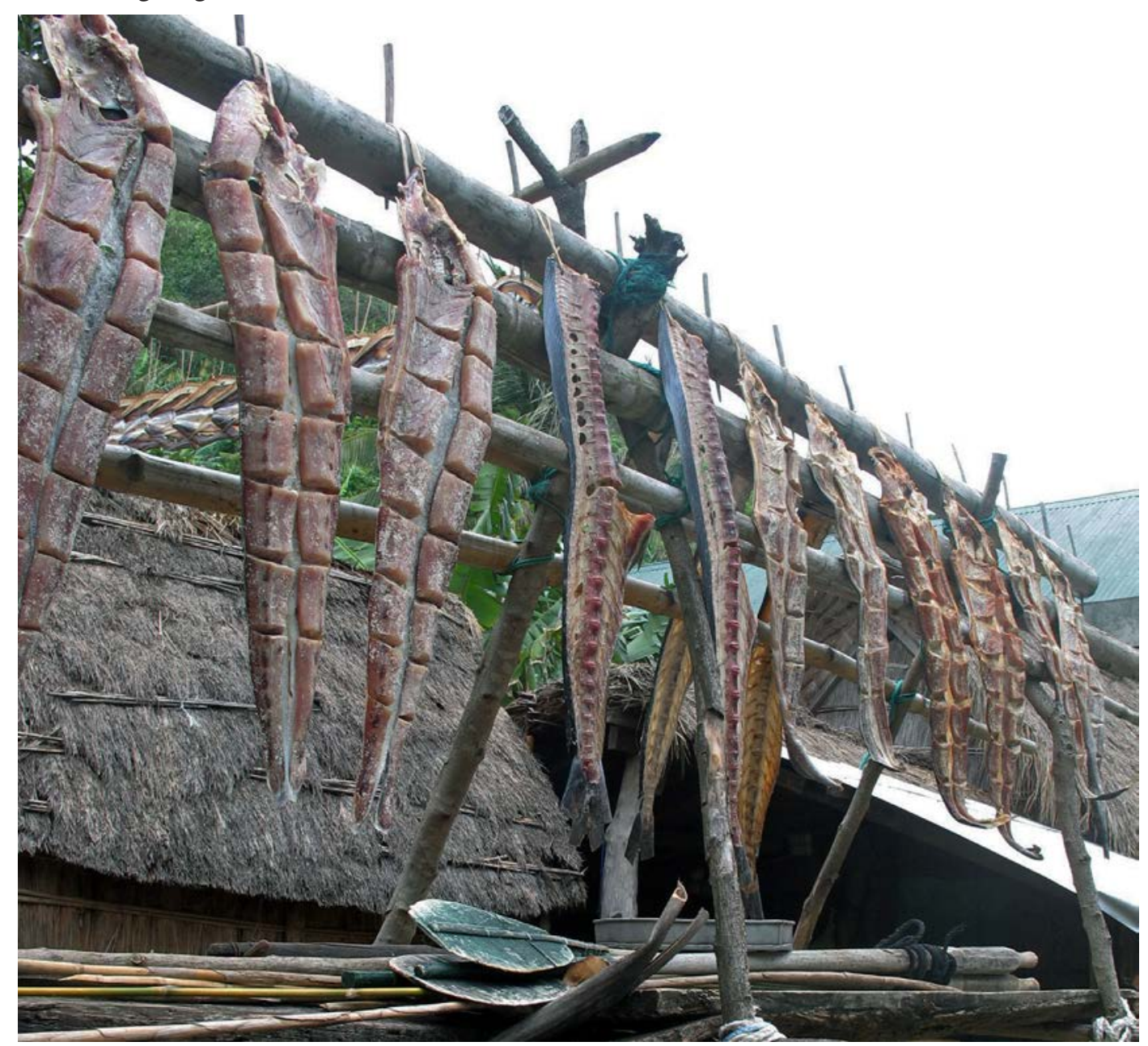

Figure 11.5. Contemporary filleting and drying of dolphinfish in the Batanes Islands.

Source: Roel Manipon.

Considering the location of the Batanes Islands and the periodically rough seas, resources would have been most accessible throughout the year near the shore. However, the rapid falling away of the seabed immediately offshore from the islands would have meant that a combination of baited angling hooks, baited and unbaited trolling lures, traps, nets and suitable ocean-going canoes could have been employed to ensure perennial supplies of fish. 


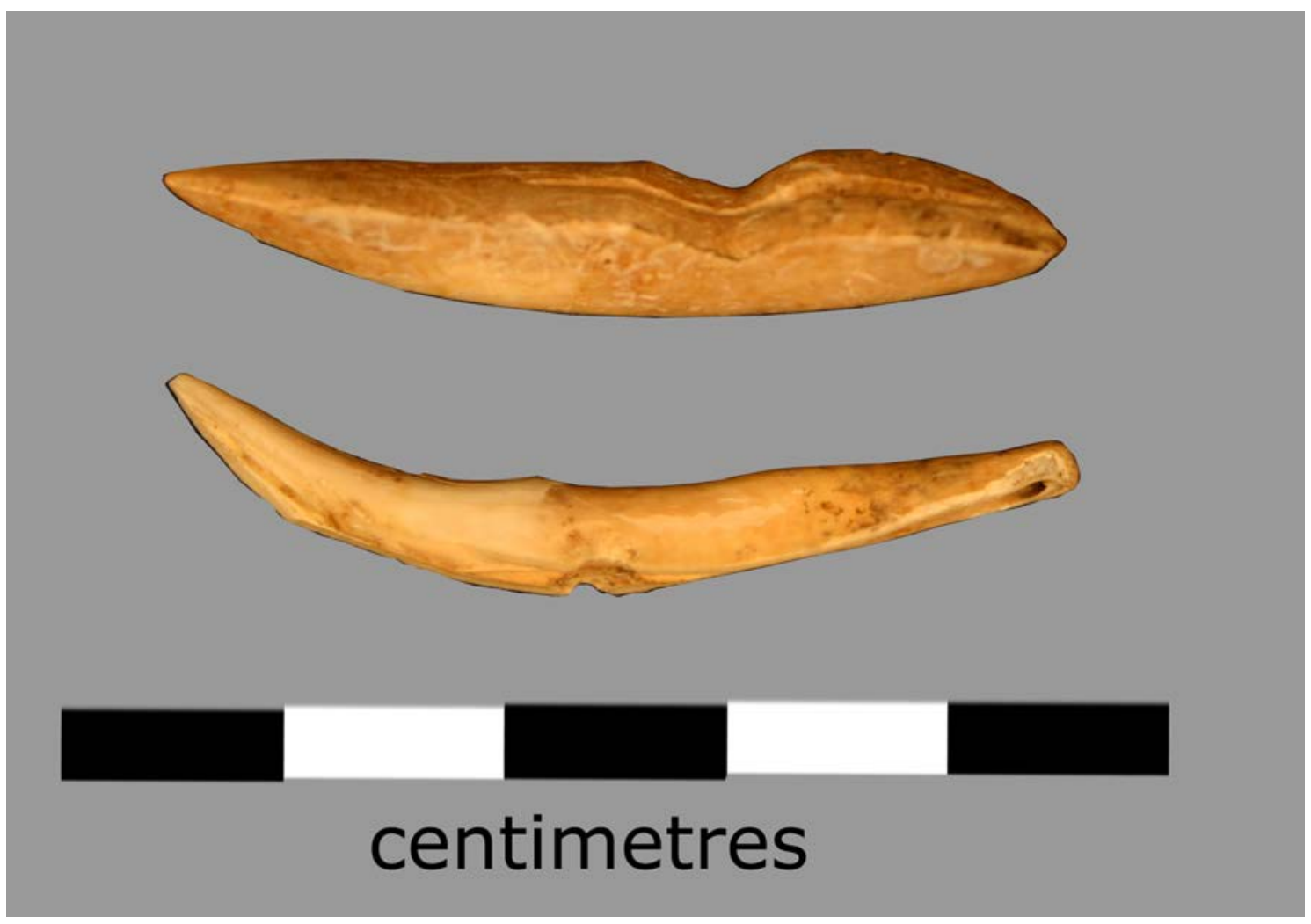

Figure 11.6. Fishing gorges from Anaro.

Source: Fredeliza Campos.

The Ivatan maintain a special reverence for dolphinfish that is still central to rituals that mark the beginning of the fishing season (Hornedo 2000; Mangahas 1994, 1996; Severino 2003). Fishing for dolphinfish coincides with the summer (March - May), when their migration occurs. A similar situation exists in Lanyu Island, located off the southeast coast of Taiwan, which also has ethnographic evidence of dolphinfish exploitation by the Yami population, who speak a Batanic language (de Beauclair 1986; Hsü 1982). The five vertebrae recovered from the sealed context of layer 4 in trench Q/R 7-9 suggest that the practice of offshore fishing for this species can be traced back in Batanes for at least 2500 years. However, it is difficult to ascertain the relative importance of dolphinfish in the early fishing economies of Batanes from a limited number of bones recovered from small trenches.

The modern Ivatan use lines baited with flying fish and motorised outrigger canoes to travel offshore for dolphinfish. A similar strategy has been observed among the local inhabitants of southern Taiwan, who use nylon trolling lines with either flying fish or plastic lures trailing behind the boat ( $\mathrm{Li}$ 1994, 2002). The propensity for pelagic fishing evidenced in the rough seas off the Batanes islands and Taiwan would suggest a more sophisticated vessel than would be required just to fish in shallow inshore reefs, perhaps with sail technology for trolling, as suggested by $\mathrm{Li}$ (2002). Hung et al. (2011) argue that these pelagic fish hunting traditions in the Marianas, southern Taiwan, Lanyu and Batanes might be an indication of cultural connections between these localities during the period of initial Austronesian migration beyond Taiwan. Possibly, the ichthyoarchaeological records of southern Taiwan and the Philippines are hinting at the existence of a maritime technology that permitted people to make the $2300 \mathrm{~km}$ open-ocean crossing between the Philippines and the Marianas around 3500 years ago (Carson et al. 2013). 
However, although the common dolphinfish is present in the zooarchaeological record from Batanes, it does not yet parallel the evidence for vigorous offshore fishing identified in nearby southern Taiwan (Campos and Piper 2009). Here, archaeological records from Eluanbi on the southernmost tip of Taiwan have shown that people specialized in open-ocean fishing, primarily for Coryphaenidae, and also for the much larger and more powerful Istiophoridae/Xiphiidae (marlins, sailfish and swordfish), from at least $1500 \mathrm{BC}$ onwards (Li 2000, 2002). Size estimation is not possible for other taxa apart from the common dolphinfish, but it would be interesting to see if bigger individuals of taxa such as Serranidae, Scombridae, and Carangidae, as well as Elasmobranchii, were caught offshore. Aggregation among pelagic fishes is also common, particularly between Scombridae and Coryphaenidae (Castro et al. 2002; Hall 1992).

Finally, although Coryphaenidae appear regularly in tropical waters, their presence is otherwise rare in the archaeology of the Indo-Pacific region (Amesbury and Hunter-Anderson 2008; Foss Leach pers. comm. 2009). The database held at the Museum of New Zealand Te Papa Tongarewa contains information on more than 75 tropical Pacific island sites and more than 125 sites in New Zealand. But none outside the Mariana Islands contain dolphinfish. The focus of prehistoric fishing throughout most of the Pacific appears to have been on inshore reef fishes (Leach and Davidson 2006; Leach et al. 1998).

\section{Conclusion}

The ichthyoarchaeological record from the Batanes indicates that the inhabitants have a long tradition of marine fishing. Nineteen different taxa were identified, comprising species commonly found over inshore reefs, such as triggerfish, porcupine fish, parrotfish and wrasses, and species from pelagic zones like the common dolphinfish. Similar reef fishes and the pelagic dolphinfish were recovered from both Itbayat and Sabtang, and from all periods of occupation, perhaps indicating that communities on both islands were participating in both inshore and offshore fishing. From Savidug Dune Site and Pamayan there appears to have been continuity in fishing tradition from the late Neolithic through the protohistoric period and up to recent times.

The archaeological record shows that fishing for Coryphaenidae has a long tradition in Batanes, stretching back at least 2500 years. Size estimations suggest that the ancient dolphinfish were of a similar size to those presently available in commercial markets. The lengths of the prehistoric specimens from Batanes ranged from $1 \mathrm{~m}$ to $1.4 \mathrm{~m}$, with the largest individuals reaching over $2 \mathrm{~m}$ and weighing perhaps as much as $40 \mathrm{~kg}$. The hunt for this particular fish certainly entailed sophisticated skills and technological acuity that would have encouraged the use of a sail together with trolling lures.

Finally, evidence for carcass processing suggests that the common practice today, in which the fish is divided longitudinally and the fillets hung to dry in the sun, is also an ancient technique. 